\title{
Promoting Liberal Learning In A Capstone Accounting Course
}

Sunita Ahlawat, The College of New Jersey, USA

Gerald Miller, The College of New Jersey, USA

Abdus Shahid, The College of New Jersey, USA

\begin{abstract}
This paper describes our efforts to integrate liberal learning principles in a capstone course within the overwhelmingly career-focused discipline of accountancy. Our approach was based on the belief that business and liberal learning courses are complementary, rather than competitive, elements of a well-rounded education. The ability to deal with ambiguity, for example, or to integrate seemingly unrelated ideas and perspectives helps young people succeed in their chosen fields.
\end{abstract}

We discuss the rationale for creating an accounting capstone course with an emphasis on incorporating a liberal learning philosophy, its implementation, our experience in the classroom, and suggestions for improvement. Overall, the course was a success; however, some modifications could be made that would make the experience a more positive one for both faculty and students.

Keywords: Liberal Learning; Accounting; Capstone; Writing Intensive; Research Emphasis

\section{INTRODUCTION}

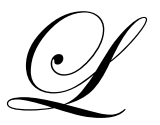

iberal education holds that the fulfillment of human potential depends upon disciplined learning. It involves acquiring foundational skills, which in turn leads to the development of transferable intellectual capacities. Foundational skills allow a person to do something; intellectual capacities enable a person to know when to do something, how to adapt it, and when to do it in a new way. In his popular book, The World is Flat, Tom Friedman (2006, pg. 302) observed, "the first, and most important, ability you can develop in a flat world is the ability to 'learn how to learn'-to constantly absorb, and teach yourself, new ways of doing old things or new ways of doing new things." Such an approach is the basis of a liberal education. This paper contributes to accounting and liberal education by providing insights and useful tips to those interested in designing and implementing a similar course at their institutions.

\section{LIBERAL LEARNING PRINCIPLES}

As students prepare for $21^{\text {st }}$ century challenges, a report released by the Association of American Colleges and Universities outlines the following four broad essential learning outcomes (Association of American Colleges and University, hereafter AAC\&U, 2007):

1. Knowledge of human cultures and the physical and natural world, which would include the study of traditional arts and sciences disciplines.

2. Intellectual and practical skills, such as critical and creative thinking, written and oral communication, and quantitative literacy.

3. Personal and social responsibility, such as civic knowledge and engagement, intercultural knowledge and competence, the ability to reason about ethics, and understanding of lifelong learning.

4. Integrative learning, including the ability to synthesize information and engage in both general and specific study. 
Liberal learning implies breadth and depth; i.e., basic knowledge in a range of disciplines, focused by more concentrated work in one. It teaches that knowledge is interconnected and that learning proceeds from a base of assumptions and perspectives. It is unrealistic to imagine that any one course can capture all four outcomes listed above. Recognizing that it is not possible to aim for all four principles in this accounting course, our course limits focus on meeting points 2 and 4 quite well, and point 3 to a lesser degree.

\section{Rationale For Incorporating Liberal Learning Philosophy In An Accounting Course}

The significance of the liberal learning philosophy was underscored in report affirming that "in a world where communication occurs frequently and instantaneously, the well-educated person must express thoughts and ideas effectively through written and oral communication." (Concordia, 2004) Being able to write well is a fundamental aspect of liberal education. Writing is not only a medium through which we communicate and persuade; it is also a means for expanding our capacities to think clearly.

Echoing these views, another report describing the findings of a survey sponsored by the AAC\&U noted that "communication skills - including writing and effective oral communication - are essential both as foundation skills for college and university learning and as lifelong skills for citizenship and the professions" (Meacham \& Gaff, 2006). Just as writing is central to learning, integrative thinking, the ability to transfer knowledge from one setting to another, and ethics and values are central to student learning goals.

The goals of liberal learning have been enumerated by many institutions of higher education. A liberally educated person is someone who (1) organizes ideas clearly, (2) develops ideas thoroughly, (3) respects and adapts to diverse audiences in formal and informal situations, (4) constructs, tests and articulates arguments, and (5) grasps how communication clarifies thought (Concordia, 2004). In the digital age, information literacy is also becoming an essential component of a liberal education. Continued growth of both electronic and printed materials makes many sources of information readily available. This necessitates students to acquire new and critical knowledge of where to find sources and how to evaluate them. Competence in this area would require a liberally educated person to (1) locate appropriate research materials by identifying and searching a variety of information resources, (2) apply an effective and efficient research methodology, (3) evaluate information and its sources critically, and (4) use information and sources ethically (Concordia, 2004).

Accountants in public practice conduct research, write memos, prepare reports, and often make presentations of solutions to client problems. Highlighting the importance of research skills for accountants, a recent study (Burke et. al., 2008) emphasized the profession's call to "educators to focus on teaching more critical-thinking skills rather than more content" and to help students acquire research skills as they prepare for the complex business environment. Recognizing the need for these competencies, the Accounting Education Change Commission, hereafter AECC, stressed the importance of research skills for accounting students in its "Position Statement Number One, Objectives of Education for Accountants." It recommended that as part of having the appropriate skills, accounting graduates should possess the "ability to present, discuss, and defend views effectively;" and "ability to locate, obtain, organize, report, and use information from human, print, and electronic sources," pg. 311 (AECC, 1990).

Mindful of the sweeping changes in the accounting profession, our department revamped the curricula to emphasize additional critical thinking and communications skills. A key component of the curriculum change was the development of a writing intensive accounting capstone course with a research focus. This course followed our college's liberal learning philosophy of helping to "ensure that students learn fundamentals of reasoning, communicating, and living in today's world" (TCNJ).

Our paper contributes to accounting and liberal education by providing insights and useful tips to those interested in designing and implementing a similar course at their institutions. It also extends the Jervis and Hartley (2005) study on designing and teaching an accounting capstone course. Jervis and Hartley emphasized learning through the case method pedagogy. Although students prepared written case reports, Jervis and Hartley's course was not writing-intensive. 


\section{A Capstone Course}

A capstone course is a method of summative evaluation in which the student is given an opportunity to demonstrate integrated knowledge and growth in the major. Capstone courses are often recommended as a key part of the accounting curriculum (Arya, Fellingham, \& Schroeder, 2003). These courses are important because they provide an opportunity to reflect on what has been learned, integrate both general education and major coursework, and help the transition to the professional world (Gardner \& Van der Veer, 1998). According to Jervis and Hartley (2005), in order to effectively end a college career and begin a professional one, capstone courses should:

- $\quad$ Promote the coherence and relevance of general education.

- $\quad$ Promote connections between general education and the academic major.

- $\quad$ Foster integration and synthesis within the academic major.

- $\quad$ Explicitly and intentionally develop important student skills, competencies, and perspectives that are tacitly or incidentally developed in the college curriculum.

- Improve seniors' career preparation and pre-professional development, that is, facilitate their transition from the academic to the professional world.

Our course embarked on learning through knowledge integration in a different way from that of Jervis and Hartley (2005) in that it required students to 1) write a twenty page research paper, (2) present and discuss assigned articles and reading materials; and 3) focus on a specific topic. While Jervis and Hartley (2005) and our paper report on implementation issues and experiences in a capstone course, this study focuses on writing, research method pedagogy and material involving a major topic.

\section{ACCOUNTING TODAY}

Accounting curricula must prepare students for their professional careers. Our writing intensive capstone course is designed to improve career preparation and pre-professional development of accounting seniors (Henscheid 2000); i.e., facilitate their transition from the academic to the professional world. The course provides a more in-depth study of major accounting topics, building on the knowledge acquired from earlier courses in the program. Students work in pairs as well as individually, studying current and historical accounting issues stemming from the basic accounting paradigms (e.g., the information economics, and the decision usefulness paradigms).

\section{Research and Writing}

This capstone course was developed in response to changes in the accounting profession and the demand for improved research and writing skills in accounting graduates. Incorporating a liberal learning philosophy in the course was in response to these changes and to our college-wide curriculum reform.

A survey of members of Beta Alpha Psi reported that students perceived exposure to accounting research in the curriculum to be limited and that there was a need for expanded coverage (Wright, 1994). Accounting professionals responding to a survey reported that the ability to write with clarity is extremely important, and that misunderstanding and misinterpretation of accounting information can have detrimental effects (Stowers and White, 1999). Clearly, strong technical and communication skills are critical to career advancement in accounting.

Recognizing the value of written communication, the American Institute of Certified Public Accountants (AICPA) revised the Uniform Certified Public Accountant (CPA) Exam to include assessment of writing skills of prospective professionals (VanZante, 2004). The U.S. Securities and Exchange Commission created a handbook "A Plain English Handbook: How to Create Clear SEC Disclosure Documents" in acknowledgment of the importance of simple, clear, and effective written communication to investors. This handbook gives tips on writing documents in a language investors can understand. Investors are more likely to understand what they are buying and to make informed judgments about whether they should hold or sell their investments. Brokers and investment advisers can make better recommendations to their clients if they can read and understand these documents quickly and easily," (p 3). As Chairman Arthur Levitt noted, "the benefits of plain English abound." 
A joint study by the Institute of Management Accountants and the Financial Executives Institute also recommended that the accounting educators put greater importance on writing skills (Siegel and Sorensen, 1994). Zinsser argues that "writing contributes to an improvement in thinking skills because a person must mentally process ideas in order to write an explanation" (Zinsser 1988, pg. 208). Besides critical thinking skills, writing facilitates understanding and memory (Bean 1996; Coffin 2003). Bean suggests that this is because "writing is both a process of doing critical thinking and a product of communicating the results of critical thinking" (Bean 1996, pg. $3)$.

Research on role of writing and its potential benefits has been established by the writing-across-thecurriculum (WAC) and writing-in-the-discipline (WID) models of learning. WAC and WID are often characterized as "writing to learn-i.e., writing as a means of acquiring information, understanding concepts, and appreciating significance in any discipline ... [versus] learning to write-i.e., acquiring the socially-mediated communication skills and genre knowledge appropriate to a specific discipline" (Broadhead, 1999, pg. 19). Drawing on theories of situated learning, Carter et al., (2007) argue that writing in the disciplines encourages socialization and learning in the disciplines.

Writing intensive courses use various kinds of writing assignments to deepen thinking about course content. The goals are to help develop students as good writers by linking their writing proficiency with the need to know more about the field of study, to engage them in emerging issues/questions in the discipline, and to have them participate in academic discourse.

As for including accounting research into the curriculum, Wright (1994) suggested two alternatives: incorporating topics as part of all courses, or devoting a course entirely to research. Simon and Alexander (1997) felt that "students can be lectured to and asked to write an essay on research design, but it is surely more appropriate to encourage students to develop this practical research skill directly. Only by 'doing' research can such skills be brought alive" (pg. 163).

Our capstone course required students to complete a standalone research paper with standard sections: Purpose and Contribution, Literature Review, Hypothesis Development, References, Data Collection and Analysis, Results/Synthesis, and Conclusion. A research paper is useful in developing students' critical thinking, written communication, and research skills, as recommended by the AECC. In essence, the capstone course makes students "learn how to learn" and goes beyond traditional accounting to further explore broader business issues.

\section{Subject Area Selection}

In the wake of the economic and financial crunch and other major corporate scandals of recent past (e.g., Enron, WorldCom), crisis is a word that has been closely associated with the accounting profession. These scandals raise questions of fundamental importance to the future of the accounting profession. The tumultuous events of the past few years ought to "motivate us to move from a debits and credits approach to an accounting education that focuses not only on technical rules but also on producing competent individuals with a functioning moral compass" (Titard et. al., 2004). It is paramount that we incorporate subjects of current interest in the business world and provide proper context to ongoing coverage of the corporate accounting scandals, including the professional and regulatory response to them. Beyond acquiring technical skills, students must understand the state of a profession they are about to enter including challenges, opportunities, and how it has evolved to its current stage.

We selected the Sarbanes-Oxley Act of 2002 (hereafter SOX) as the most appropriate, timely, and relevant subject area for the course as it presented several advantages: 1) the significance of the SOX legislation; 2) the fact that more than five years had passed since it was enacted and much had been written about it; 3) it is a controversial piece of legislation, as many have questioned whether the benefits exceed costs; and 4) knowledge of SOX is in demand by CPA firms and this knowledge would benefit graduating students in the job market. Additionally, although SOX has had a widespread impact on the accounting profession, it had not been covered in any one accounting course at our college. 


\section{The Sarbanes-Oxley Act of 2002}

Widely publicized accounting failures in 2001 and 2002 were followed by the passage of SOX and the creation of the Public Company Accounting Oversight Board (PCAOB). SOX is considered by many to be the most significant legislation affecting accounting since the Securities Acts of 1933 and 1934 as it included far-reaching sections on corporate governance and financial disclosures. Students must understand what SOX entails, its consequences, its impact on accounting practice, and its impact on corporations and management decision making. SOX imposes additional disclosure requirements and considerable corporate governance mandates. It is quite unprecedented in the history of federal securities legislation (Romano, 2005).

There are eleven titles in SOX, each with several sections that describe specific mandates and requirements for financial reporting. They are: 1) Establishment of the Public Company Accounting Oversight Board to oversee public accounting firms, 2) Auditor Independence to limit conflicts of interest, 3) Corporate Responsibility - senior executives take individual responsibility for the accuracy and completeness of corporate financial reports, 4) Enhanced Financial Disclosures including off-balance-sheet transactions, pro-forma figures and stock transactions of corporate officers, 5) Analysts Conflict of Interest defines code of conduct and includes measures designed to help restore investor confidence, 6) Commission Resources and Authority defines the SEC's authority to censure or bar securities professionals from practice, 7) Studies and reports requires the SEC to perform various studies and report their findings, 8) Corporate and Criminal Fraud Accountability describes specific criminal penalties for manipulation, destruction or alteration of financial records, 9) White Collar Crime Penalty Enhancement increases the criminal penalties associated with white-collar crimes and conspiracies, 10) Corporate Tax Returns requires the CEO to sign the company tax return, and 11) Corporate Fraud Accountability identifies corporate fraud and records tampering as criminal offenses (SOX, 2002).

The main controversy arising from SOX is whether the benefits exceed the costs associated with implementation of this legislation. From the outset the business community expressed substantial concerns about cost of compliance (Zhang, 2007). After an extensive review of empirical literature relating the SOX, Romano (2005) concluded that the SOX mandates are less likely to improve audit quality and will not benefit the investors. Romano also argued that SOX was hurriedly enacted after corporate scandals without giving consideration of its substantial costs compared to the corresponding benefits. Executives are concerned about the benefits of SOX to the shareholders. The compliance costs are not only the incremental dollar cost but also the opportunity cost of diverting executives' attention from day-to-day businesses (Solomon and Cassell, 2004). In summary, SOX is timely, controversial, and mandated. Students would benefit from acquiring an in-depth understanding of the law and its consequences, and the impact on accounting practice, corporations and management decision-making.

\section{IMPLEMENTATION ISSUES}

This course is a four-credit course, offered with a prerequisite that the student must be an accounting major with senior standing. The course description is: This writing intensive course is designed for students who will be accounting professionals. The broad objective of this course is to integrate and enhance study of accounting topics, concepts and methods, building on the knowledge acquired from earlier courses in the program. This course is designed to address the following program learning goals: accounting concepts, critical thinking in accounting, and effective communication.

Students take three writing intensive courses during their time at the college. The first of these is a freshman level seminar; the second is a mid-level writing intensive course designated for the major and taken during the sophomore or junior year, and the third is a writing intensive capstone course in the major. Writing intensive capstone courses must be reviewed by the college's Writing Program Committee and then approved by the Liberal Learning Program Council.

Writing intensive courses use various kinds of writing assignments to deepen thinking about course content. The goals are to help develop students as good writers by linking their writing proficiency with their desire to know more about the field of study, to engage in emerging issues/questions in the discipline, and to have students become participants in academic discourse. Class sections were capped at 18 students. 


\section{Learning Goals}

The course addresses three learning goals while fulfilling college wide liberal learning requirements for a writing-intensive course with a research emphasis. These are: (1) the use, interpretation, and integration of accounting information, (2) the ability to conduct research, and (3) the ability to think critically and communicate accounting information, both orally and in writing, to a target audience.

These goals guided our class discussions and fostered a greater understanding of accounting issues (e.g., revenue recognition, mark-to-market) that had arguably led to corporate failures such as Enron and WorldCom. The learning objectives required students to understand various views, implications, and strengths and weaknesses of SOX. At the conclusion of the course, students were expected to know how to:

- $\quad$ construct complex analyses, supported by ideas from relevant literature

- $\quad$ communicate complex ideas clearly and cohesively in writing and in speaking

- $\quad$ identify and correct weaknesses in presentation of ideas in a professional manner

\section{Course Materials}

Writing, speaking, and thinking are interdependent endeavors; developing a command of one means sharpening another. The course materials consisted of a documentary and various readings (monograph, journal articles, cases, book chapters etc.). The first step in assembling the material was to take an inventory of articles that had been written about SOX during the past five years. Articles appropriate for classroom presentation by the students were selected and scanned so that they could be posted on the college's online course management system.

The articles came from scholarly and professional journals as well as newspapers such as the Wall St. Journal and the New York Times. Articles from foreign journals and newspapers were included to provide an international perspective. It is important to note here that many readings came from professional journals such as the Journal of Accountancy and the CPA Journal. Some may argue that these journals are not "scholarly" enough and that the articles perhaps lack rigor. Given that this was not a graduate seminar, we believe that the course achieved a good balance between scholarly and professional publications without sacrificing relevance. In fact, it was an opportunity to introduce students to journals they are more likely to read as professionals, not just academic publications. This course provided an excellent opportunity to contrast different types of research and rigor. The selection of our reading list followed an approach to teaching and learning that ensures that we prepare students for the actual "world of work" (Schneider 2005, pg. 3).

Specifically, the readings were selected to foster students' understanding of the various aspects arising from the law, including implications of SOX, provisions regarding the role of the PCAOB, auditor independence, corporate responsibility, corporate disclosures, and cost of implementation. Table 1 presents a list of sample readings. A broad range of topics were covered, including the background and events that led to the enactment of SOX, what the law entails, business ethics and conflict of interest, accountability and independence, corporate governance and internal controls, cost of compliance, international and small company perspective, challenges for non-profit organizations, and enforcement issues.

Understanding of various concepts learned in prior courses was crucial to fully appreciating the context and the content of assigned readings. The course materials were selected to promote knowledge integration and expansive learning. For example, the course began with three different items: 1) the documentary Enron-The Smartest Guys in the Room, 2) the article "The Rise and Fall of Enron" from Journal of Accountancy (2002) and, 3) the case study "Behind Closed Doors at WorldCom" from Issues in Accounting Education (2001). The documentary painted a vivid picture of Enron's faulty and corrupt business practices that led to its demise; the JOA article tells a cautionary tale of when a company looks too good to be true, it usually is; and the WorldCom case provided students an opportunity to study the largest accounting scandal in history from an internal financial accounting perspective. Beyond the scandals, students needed to connect accounting dots in each instance. That is, what accounting issues were at stake? More specifically, what accounting principles were violated and how? To understand how companies "cooked the books," a thorough understanding of the revenue recognition principle was 
required. This principle is first introduced in an introductory accounting class and further applied in intermediate and advanced accounting courses. A broad range of discussions ensued encompassing topics such as the role of special purpose entities and off-balance sheet financing. A good grounding in foundational concepts was required for students to appreciate how these concepts were used or misused.

Table 1: List of Selected Readings

\begin{tabular}{|c|c|}
\hline Issue/Topic & Material \\
\hline $\begin{array}{l}\text { Background \& } \\
\text { Overview }\end{array}$ & $\begin{array}{l}\text { DOCUMENTARY: Enron - The Smartest Guys in the Room (2005) } \\
\text { ARTICLE: The Rise and Fall of Enron, Journal of Accountancy Online Issues April } 2002 \\
\text { CASE: Behind Closed Doors at WorldCom: 2001, Issues in Accounting Education, Feb. 2004. Vol. } 19\end{array}$ \\
\hline The Law & $\begin{array}{l}\text { BOOK: Understanding Sarbanes-Oxley Act of 2002: Impacting the Accounting Profession by Beasley \& } \\
\text { Elder, } 2005 \text { Prentice Hall } \\
\text { ARTICLE: The Social Construction of Sarbanes-Oxley, Michigan Law Review, June 2007, Issue } 8 \\
\text { ARTICLE: The PCAOB's Primary Mission: Improving Confidence in Financial Reporting, The CPA } \\
\text { Journal }\end{array}$ \\
\hline Business Ethics & $\begin{array}{l}\text { CASE: Hard Times and Harder Choices: An Instructional Case Focusing on Ethical Responsibilities of } \\
\text { CPAs in Public Practice," Issues in Accounting Education, Nov. 2004, Vol. } 19 . \\
\text { ARTICLE: The Role of Attorneys Under Sarbanes-Oxley: The Qualified Legal Compliance Committee as } \\
\text { Facilitator of Corporate Integrity, American Business Law Journal, Fall } 2006 \text { Vol.43, Issue 3. }\end{array}$ \\
\hline $\begin{array}{l}\text { Accountability \& } \\
\text { Independence }\end{array}$ & $\begin{array}{l}\text { ARTICLE: A Case for Responsible Reporting," The Internal Auditor April 2006, Vol. } 63 \\
\text { CASE: Thinking Outside of the Box (of wine, that is): An Exercise in Independence," Issues in Accounting } \\
\text { Education, Aug. 2004, Vol. } 19 .\end{array}$ \\
\hline $\begin{array}{l}\text { Corporate } \\
\text { Governance }\end{array}$ & $\begin{array}{l}\text { CASE: Dynamic Data: Corporate Governance and Auditors' Evaluation of Accounting Estimates, Issues in } \\
\text { Accounting Education, Feb. 2005, Vol. } 20 \\
\text { ARTICLE: Audit Committees Oversight Responsibilities Post Sarbanes-Oxley Act, American Journal of } \\
\text { Business, Fall 2007, vol. 22, Issue 2. }\end{array}$ \\
\hline Audit Process & ARTICLE: How Sarbanes-Oxley Will Change the Audit Process, Journal of Accountancy, Sept. 2003. \\
\hline Internal Controls & $\begin{array}{l}\text { ARTICLE: Sarbanes-Oxley Section } 404 \text { and Internal Controls, The CPA Journal, Oct. 2007, Vol. } 77 . \\
\text { ARTICLE: The New Importance of Materiality by James Brady Vorhies in the Journal of Accountancy, May } \\
2005 .\end{array}$ \\
\hline $\begin{array}{l}\text { Cost of } \\
\text { Compliance }\end{array}$ & $\begin{array}{l}\text { ARTICLE: Accounting for Compliance: Instead of viewing compliance as a necessary evil, advisors should } \\
\text { see it as a cost of doing business and learn how to quantify that cost, Financial Planning, New York: Sep 1, } \\
2006 \text {. }\end{array}$ \\
\hline $\begin{array}{l}\text { Small Company } \\
\text { perspective }\end{array}$ & $\begin{array}{l}\text { ARTICLE: Do Small Companies Need a } 404 \text { Audit? Financial Executive Sep 2006. Vol.22, Issue } 7 . \\
\text { ARTICLE: Guidance for Smaller Public Companies Reporting on Internal Controls, The CPA Journal Sep } \\
\text { 2006, Vol.76 }\end{array}$ \\
\hline $\begin{array}{l}\text { International } \\
\text { perspective }\end{array}$ & $\begin{array}{l}\text { ARTICLE: How Has SOX Affected Foreign Private Issuers? Strategic Finance, November } 2007 \\
\text { ARTICLE: Has SOX Led to A Chilling in the U.S. Cross Listing Market? CPA Journal, March } 2007 \\
\text { ARTICLE: Perspectives of Corporate Governance in the U.S. and Abroad," The Business Review, Summer } \\
\text { 2006, Vol 5. }\end{array}$ \\
\hline $\begin{array}{l}\text { Challenges for } \\
\text { non-profits }\end{array}$ & $\begin{array}{l}\text { ARTICLE: What's Good for the Goose is Not Good for the Gander: Sarbanes-Oxley-Style Nonprofit } \\
\text { Reforms, Michigan Law Review, June 2007, Issue 8, Vol. } 105 \\
\text { ARTICLE: Business \& Industry/Not-For-Profit Cherry Picking for Sarbanes-Oxley by Richard S. Savich in } \\
\text { the Journal of Accountancy, June } 2006\end{array}$ \\
\hline Enforcement & $\begin{array}{l}\text { ARTICLE: SOX and Whistle blowing, Michigan Law Review, June } 2007 . \\
\text { CASE: Putting the Clock Back: Microstrategy Inc., Issues in Accounting Education, May 2004, Vol. } 19 .\end{array}$ \\
\hline
\end{tabular}


In general, the capstone course called upon students to recall and review (if necessary) concepts and issues they had learned in various prior courses, such as the concepts of cost (e.g., voluntary vs. mandatory), internal control (e.g., preventive, detective, and corrective), and corporate governance (e.g., role and composition of an audit committee). Addressing liberal learning principle \# 4 (discussed earlier), Table 2 captures the integrative elements of this course. The reading list reinforced this principle by including general topics (e.g., the importance of auditor accountability and independence) and specific issues (e.g., types of misleading financial reporting, specific loopholes exploited).

Table 2: Elements of Content Integration

\begin{tabular}{|c|c|}
\hline Topic & Accounting Program/Courses \\
\hline Background \& Overview & $\begin{array}{l}\text { - Financial Accounting and Reporting } \\
\text { - Introduction to Accounting Profession }\end{array}$ \\
\hline The Law & $\begin{array}{l}\text { - } \text { Business and Securities Laws } \\
\text { - Legal \& Regulatory Environment of Business }\end{array}$ \\
\hline $\begin{array}{l}\text { Business Ethics \& } \\
\text { Conflict of Interest }\end{array}$ & $\begin{array}{l}\text { - Curriculum wide (e.g., IMA professional code of conduct introduced in } \\
\text { Managerial Accounting) }\end{array}$ \\
\hline Accountability \& Independence & $\begin{array}{l}\text { - Auditing (e.g., types of misleading reporting that led to problems, loopholes } \\
\text { exploited } \\
\text { - Introduction to Accounting Profession }\end{array}$ \\
\hline Corporate Governance & $\begin{array}{l}\text { - } \\
\text { - Auditing (e.g., composition of audit committee) } \\
\text { AIS on corporate strategy and culture) } \\
\text { - Strategic Management (Corporate Governance) }\end{array}$ \\
\hline Audit Process & - Auditing \\
\hline Internal Controls & $\begin{array}{l}\text { - Financial Accounting and Reporting } \\
\text { - Auditing } \\
\text { - Accounting Information Systems (e.g., controls \& information systems; } \\
\text { preventive, detective, corrective controls ) } \\
\text { - Strategic Management (e.g., internal scanning: organizational analysis) }\end{array}$ \\
\hline Cost of Compliance & $\begin{array}{l}\text { - Cost and Managerial Accounting (e.g., concepts of cost (direct vs. indirect, } \\
\text { voluntary vs. mandatory, incremental costs, opportunity cost) } \\
\text { - Microeconomics }\end{array}$ \\
\hline Small Company perspective & - $\quad$ Economies of scale \\
\hline International perspective & $\begin{array}{l}\text { - Intermediate Accounting (e.g., IFRS, international accounting issues) } \\
\text { - Microeconomics (the United States in the global economy; reasons for } \\
\text { international trade; law of comparative advantages) } \\
\text { - International Business is a required course }\end{array}$ \\
\hline Challenges for non-profits & - $\quad$ Advanced Accounting \\
\hline Enforcement & $\begin{array}{l}\text { - Legal and Regulatory Environment (the legal system, the court system) } \\
\text { - Strategic Management (evaluation and control) }\end{array}$ \\
\hline
\end{tabular}

\section{Student Research, Writing and Presentations}

Learning never happens in isolation, and the quality of student experience often depends on their ability to collaborate fully with others. As such, we decided that students would work in pairs and make three presentations during the semester. Students presenting articles were required to post discussion questions on our college's online course management system the day prior to the presentation. Students not presenting were graded on class participation and had to attend class in order to earn participation points.

Targeting liberal learning principle \# 2, the writing component of the course required each student to submit three pieces of individual writing: 1) a one-half to one page proposal/outline describing the topic of the paper, due at the end of the seventh week of the semester; 2) a draft of the paper, including a statement of the purpose and contribution of the paper, a literature review, a statement of the hypothesis or research question, and 
references, due at the end of the eleventh week, and 3) the final paper consisting of those items included in the first draft as well as the data collection \& analysis, results/synthesis, and conclusion, due at the end of the thirteenth week. The aim of these writing assignments was to foster critical (e.g., through literature review) and creative thinking (e.g., through hypotheses development), as well as written communication.

The amount of ungraded, informal or draft writing was much higher than 20 pages. Students were encouraged, but not required to select a topic that was related to SOX. The flexible approach on topics was adopted to accommodate intellectual curiosity while meeting learning goals. All topics, whether related to SOX or not, had to be approved by the professors before students moved on with their research.

\section{Tutorial on Research}

Conducting an efficient and effective search for material is crucial to a successful research project. Since most students had not written an academic research paper prior to this course, they were given a tutorial on how to navigate various library resources, perform a literature review and develop a hypothesis. The business librarian at our college, who is a Certified Public Accountant, came to each section to conduct the tutorial. The tutorial covered five important aspects, 1) getting started, generating ideas, selecting a topic, 2) finding data to support research (U.S. and international statistics, Fama \& French data library etc), 3) finding articles and performing scholarly research about a topic, 4) finding and analyzing company information (financial statements, SEC Reports, etc.), and 5) using guides to write well (citing resources correctly and avoiding plagiarism). A writing workshop was also held to describe the process of writing research papers and covered areas such as hypothesis development, data collection and analysis of data.

\section{Assessment}

The grades were based on student presentation, class participation, and the research paper. Specific weights for each element were apportioned as follows:

Class presentation (pair):

Presentation \& Handout $\quad 25.0 \%$

Questions posted online $\quad 7.5 \%$

Class participation (individual):

Non-presenter $\quad 12.5 \%$

Comments posted online $\quad 5.0 \%$

Paper (individual):

Proposal/outline $\quad 12.5 \%$

Draft $\quad 12.5 \%$

Final version (20-25 pages) $\quad 25.0 \%$

Total $\overline{100 \%}$

Presentation points were awarded on the basis of quality of class presentation, handouts, and timely posting of online discussion questions/comments. Students not presenting were awarded points for class participation on the basis of quality and quantity of thoughtful response to questions or comments, as follows: $5=$ very good (more than two constructive comments per class); $3=$ average (two comments per class) and $1=$ minimal (one general comment per class). Students received no points if they either did not participate or were absent. Points awarded for class participation motivated students to read the articles, review the discussion questions and participate in the discussions. Under this system, the quality of student presentations and overall class discussions improved over the course of the semester as students made more constructive and insightful comments. The research paper (proposal, draft and the final version) was graded using a common rubric. 


\section{Grading Rubric}

A grading rubric, presented in Exhibit 1, was developed early on in the course and shared with students as they began to develop ideas for their proposals. It contains seven items: 1) purpose and contribution, 2) literature review, 3) hypothesis development, 4) references, 5) data collection and analysis, 6) results/synthesis, and 7) conclusion.

Within each category, a student could receive one point for a poor effort; two points for a limited effort; three points for a fair effort; four points for a good effort, and five points for an excellent effort. Fifty percent of a student's grade in the course was based on the three writing assignments, with the proposal worth $12.5 \%$, the first draft worth $12.5 \%$, and the final paper worth $25 \%$.

\section{Exhibit 1}

\begin{tabular}{|c|c|c|c|c|c|c|c|c|}
\hline \multicolumn{4}{|c|}{$\begin{array}{l}\text { Research Paper Grading Rubric } \\
\text { Capstone Seminar in Accounting }\end{array}$} & \multicolumn{3}{|l|}{ Name: } & & \\
\hline & \multirow[b]{2}{*}{ Category } & \multirow{2}{*}{$\begin{array}{c}\text { Poor } \\
1\end{array}$} & \multirow{2}{*}{$\begin{array}{l}\text { Limited } \\
2\end{array}$} & \multirow{2}{*}{$\begin{array}{c}\text { Fair } \\
3\end{array}$} & \multirow{2}{*}{$\begin{array}{c}\text { Good } \\
4\end{array}$} & \multirow{2}{*}{$\begin{array}{l}\text { Excellent } \\
\quad 5\end{array}$} & \multicolumn{2}{|c|}{ Scores } \\
\hline & & & & & & & Draft & Final \\
\hline \multirow{3}{*}{$\begin{array}{l}\bar{\pi} \\
0 \\
0 \\
0 \\
0 \\
0 \\
0\end{array}$} & $\begin{array}{l}\text { Purpose \& } \\
\text { Contribution }\end{array}$ & $\begin{array}{l}\text { Unfocused; cannot determine } \\
\text { purpose; no reasons for its } \\
\text { importance }\end{array}$ & $\begin{array}{l}\text { Rambling introduction; vague } \\
\text { description of purpose; weak } \\
\text { reasons for its importance }\end{array}$ & $\begin{array}{l}\text { Obvious (uninteresting) } \\
\text { introduction; adequate } \\
\text { statement of purpose; provides } \\
\text { adequate reasons for its } \\
\text { importance }\end{array}$ & $\begin{array}{l}\text { Clear introduction; clear } \\
\text { statement of purpose in a single } \\
\text { sentence; fairly good reasons for } \\
\text { its importance; }\end{array}$ & $\begin{array}{l}\text { Engaging introduction; clear \& } \\
\text { concise statement of purpose; } \\
\text { strong reasons for its } \\
\text { importance; }\end{array}$ & & \\
\hline & $\begin{array}{l}\text { Literature } \\
\text { Review }\end{array}$ & $\begin{array}{l}\text { Weak review; wanders \& jumps } \\
\text { around; transition confusing \& } \\
\text { unclear; inappropriate } \\
\text { generalizations; errors of fact }\end{array}$ & $\begin{array}{l}\text { Limited review; details too } \\
\text { general or off-topic, often } \\
\text { wanders or jumps around; few } \\
\text { clear transitions; inappropriately } \\
\text { repetitive }\end{array}$ & \begin{tabular}{|l|} 
Adequate review; offers \\
somewhat obvious support; may \\
wander occasionally; a few \\
unclear transitions
\end{tabular} & $\begin{array}{l}\text { Good review; clear transition } \\
\text { from point to point; appropriate } \\
\text { supporting details and/or } \\
\text { examples }\end{array}$ & $\begin{array}{l}\text { Thorough review; Details are } \\
\text { germane, original, convincingly } \\
\text { interpreted; ideas connected } \\
\text { coherently from point to point }\end{array}$ & & \\
\hline & $\begin{array}{l}\text { Hypothesis } \\
\text { development }\end{array}$ & $\begin{array}{l}\text { Undeveloped or cryptic support } \\
\text { for ideas; faulty assumptions }\end{array}$ & $\begin{array}{l}\text { Simplistic \& vague; ideas not } \\
\text { fully developed; assumptions not } \\
\text { recognized }\end{array}$ & $\begin{array}{l}\text { Fair but less original } \\
\text { reasoning/discussion; some } \\
\text { assumptions recognized }\end{array}$ & $\begin{array}{l}\text { Good reasoning/discussion } \\
\text { leading to the development of } \\
\text { ideas; assumptions not always } \\
\text { made explicit }\end{array}$ & $\begin{array}{l}\text { Substantial breadth \& depth to } \\
\text { the logical development of ideas; } \\
\text { assumptions made expilcit }\end{array}$ & & \\
\hline & References & \begin{tabular}{|l|} 
Neglect important sources; \\
overuse of quotation or \\
paraphrase to substitue writer's \\
own ideas (possibly use source \\
without acknowledgement); \\
cited incorrectly
\end{tabular} & $\begin{array}{l}\text { use some relevant sources but } \\
\text { lack variety and/or skillful } \\
\text { combination of sources; } \\
\text { quotations too long; cited } \\
\text { inconsistently }\end{array}$ & \begin{tabular}{|l|} 
use adequate \# of relevant \\
sources to support \& extend \\
ideas; some substitution of \\
writer's own development of \\
ideas; adequate combination of \\
material; some overuse of \\
quotes; cited correctly
\end{tabular} & $\begin{array}{l}\text { use fair \# of relevant sources to } \\
\text { support \& extend but not } \\
\text { substitute writer's own } \\
\text { development of ideas; fair } \\
\text { combination of material; doesn't } \\
\text { overuse quotes; cited correctly }\end{array}$ & $\begin{array}{l}\text { use a variety of relevant sources } \\
\text { to support, extend \& inform but } \\
\text { not substitute writer's own } \\
\text { development of ideas; skillful } \\
\text { combination of material; doesn't } \\
\text { overuse quotes; cited correctly }\end{array}$ & & \\
\hline \multirow{3}{*}{$\begin{array}{l}\frac{\hbar}{4} \\
\frac{1}{0} \\
\frac{1}{\pi} \\
\frac{1}{4}\end{array}$} & $\begin{array}{l}\text { Data } \\
\text { Collection \& } \\
\text { Analysis }\end{array}$ & $\begin{array}{l}\text { Failed to gather } \\
\text { data/information and therefore } \\
\text { could not do analysis }\end{array}$ & $\begin{array}{l}\text { Collected/gathered some data, } \\
\text { but it was limited in usefulness } \\
\text { and resulted in weak analysis }\end{array}$ & \begin{tabular}{|l|} 
Data collected and organized in a \\
clear manner; conclusions could \\
be supported by stronger \\
evidence.
\end{tabular} & $\begin{array}{l}\text { Data collected and organized in a } \\
\text { clear manner; student shows } \\
\text { good effort in analyzing the } \\
\text { evidence collected. }\end{array}$ & $\begin{array}{l}\text { Information collected from a } \\
\text { variety of sources; complete and } \\
\text { correct analysis of data is } \\
\text { provided. }\end{array}$ & & \\
\hline & $\begin{array}{l}\text { Results / } \\
\text { Synthesis }\end{array}$ & $\begin{array}{l}\text { Weak or no results due to failure } \\
\text { to gather data/information }\end{array}$ & $\begin{array}{l}\text { Results stated but visible } \\
\text { observations missing; analysis of } \\
\text { data contains errors }\end{array}$ & $\begin{array}{l}\text { Visible observations provided; } \\
\text { analysis of data contained few } \\
\text { errors }\end{array}$ & $\begin{array}{l}\text { Visible observations provided; } \\
\text { correct analysis of data; } \\
\text { adequate discussion \& synthesis }\end{array}$ & $\begin{array}{l}\text { All visible observations provided; } \\
\text { superior discussion and synthesis } \\
\text { of results }\end{array}$ & & \\
\hline & Conclusion & $\begin{array}{l}\text { No conclusions drawn; paper just } \\
\text { ends }\end{array}$ & $\begin{array}{l}\text { Incomplete and/or unclear; no } \\
\text { restatement of thesis }\end{array}$ & $\begin{array}{l}\text { Conclusion is recognizable; } \\
\text { Thesis is restated, but not near } \\
\text { the beginning }\end{array}$ & $\begin{array}{l}\text { Reasonable, explicit conclusion; } \\
\text { Restatement of thesis }\end{array}$ & $\begin{array}{l}\text { Strong, engaging conclusion; } \\
\text { effective restatement of the } \\
\text { thesis }\end{array}$ & & \\
\hline
\end{tabular}




\section{OUTCOMES, EXPERIENCE AND CONCLUSIONS}

While most students selected topics related to SOX, many tackled hot topics that have been in the news. Table 3 presents a sample of student research topics. Each topic was classified in one of the following four categories: 1) Sarbanes-Oxley, 2) IFRS/GAAP, 3) Auditing, and 4) Other. As Table 3 shows, students came up with some interesting and catchy titles.

Table 3: Sample List of Student Research Paper Topics

\begin{tabular}{|c|c|}
\hline Area & Topic / Title \\
\hline Sarbanes Oxley & $\begin{array}{l}\text { The US Loss of Competitive Edge Is Not Due to Sarbanes-Oxley } \\
\text { O The Effects of Sarbanes-Oxley on the IPO market in the United States } \\
\circ \text { A Three Tier System of Accounting for Businesses Under SOX }\end{array}$ \\
\hline IFRS \& GAAP & $\begin{array}{l}\circ \text { Going Global: An Analysis of the Convergence of U.S. and International Accounting Standards } \\
\circ \text { Adoption of IFRS: Why, Why now, and What it means for us? }\end{array}$ \\
\hline Auditing & $\begin{array}{ll} & \text { The Case for Audit Partner Rotation vs. Audit Firm Rotation. } \\
\circ & \text { The Effect of Auditor Independence on Non-Big Four Firms } \\
\circ & \text { Auditing Standards No. 5: An Improvement Over Auditing Standard No. } 2 \\
\end{array}$ \\
\hline Other & $\begin{array}{l}\text { The Urge to Merge: The Consolidation of the Accounting Industry, Past, Present, and Future. } \\
\text { Is History Repeating Itself?: Crisis in the Banking Industry } \\
\text { The Accounting Profession: Raising the Bar on Corporate Lawyers } \\
\text { - An Approach to Fixing the Stock Option Backdating problem }\end{array}$ \\
\hline
\end{tabular}

The grading rubric results show that the quality of student papers improved significantly from the draft to the final stage. Based on all papers $(\mathrm{N}=51)$ submitted across the three sections, the average points earned on the final version were greater than points earned on draft for each category: Purpose and Contribution (3.86 vs. 3.29); Literature Review (4.02 vs. 3.51); Hypothesis Development (3.80 vs. 3.14); Data Collection and Analysis (4.08 vs. 3.61); Results and Synthesis (4.04 vs. 3.37); Conclusion (3.86 vs. 3.12); References (4.10 vs. 3.65). Using 2-tailed T-test, we found each of these differences to be statistically significant $(\mathrm{p}<.01)$. These results indicate that the pursuit of liberal learning principle \# 2 was successful. Students' critical and creative thinking, based on their papers and writing skills, improved considerably. Student papers also showed a high level of knowledge integration and synthesis which underscores the realization of liberal learning principle \# 4. Students were able to engage in general study of a topic as well as hone in on specific issues. For example, the paper, "The Effects of Sarbanes-Oxley on the IPO Market in the United States," discussed SOX in general and how specific provisions of this law were seen as onerous, making initial public offering in the U. S. stock exchanges less attractive. Specific IPO data from the London Stock Exchange versus the New York Stock Exchange was compared to a gauge the impact of SOX in the post-enactment period.

\section{Feedback and Student Evaluation}

Students received feedback throughout the semester. Two class days were reserved for instructors to formally review the proposal and first draft with each student. As a result of one-on-one discussions, we found that some students were having difficulty completing a literature review. As previously described, we addressed this problem with the help of our business librarian, who gave students a tutorial on available library resources and on conducting a literature review.

Student feedback is required for every course taught at our college. The feedback form includes twentyfive questions, sixteen of which relate to the instructor's performance and seven relate to the course itself. Average scores based on the seven key course specific items show encouraging results. On a five point scale $(1=$ strongly disagree to $5=$ strongly agree), the average scores for the seven items are as follows:

1. Assignments added to my understanding of the course $=4.02$

2. Collaborative work with classmates added to my understanding of the course $=4.07$

3. I acquired valuable skills and knowledge in this course $=4.00$

4. I found the course intellectually challenging $=3.96$ 
5. I increased my ability to analyze and critically evaluate ideas $=4.15$

6. Required readings were valuable and enriched my learning experience $=4.07$

7. The course materials were well prepared and carefully explained $=3.95$

These results indicate that students felt that their analytical and critical thinking skills were enhanced in this course, validating our focus on liberal learning principle \# 2.

\section{Our Experience}

On three occasions during the semester, students were responsible for presenting journal articles to the rest of the class. They worked in pairs when presenting these articles; those who did not select a co-worker were matched up by the professor. A schedule of journal article presentations was given to students in the first week so they knew which days they would be presenting. Each pair of students was responsible for posting discussion questions the day prior to the day of the presentation. All articles were either about or related to SOX and had been written within the past five years.

Several challenges surfaced during the course. First of all, we observed "senioritis and job effects" that made some students less motivated. That is, many of the seniors in the course had already accepted a full time position upon graduation and some seemed to feel that they did not really "need" the course. In addition, the group of seniors taking the course was the first class that had the capstone course as a graduation requirement. As a result, there was some resentment in having to complete a senior level course that included a significant amount of work during the last semester of college.

Secondly, in retrospect, too many journal articles were assigned for review. Each pair of students was required to make three presentations of assigned journal articles during the semester, including the preparation of and prior-day distribution of discussion questions. Many of the presentations included multiple journal or newspaper articles, and students presenting were responsible for leading the discussion of the articles. Our specific instructions required students to post their "thoughts and discussion questions for the day, in light of prior class learning, at least one day before the class meeting day." Despite the instructions, some students did not post discussion questions in a timely manner, sometimes even waiting until close to or after midnight. Our assessment at the completion of the course was that two presentations of journal articles would have been more appropriate, with the last third of the semester being devoted primarily to writing the paper. In addition, better instructions with specific time deadlines were needed to get the discussion questions posted by a reasonable time on the day prior to the article presentations.

Third, we assumed that students would be able to complete a literature review for their individual research paper. However, as we discussed earlier, this was not always the case. We made arrangements to address this, a fundamental weakness. Any institution considering a writing capstone course with a major research paper should make sure that conducting a literature review is either covered in an earlier course or early in the semester of the capstone course.

Finally, for some students, class participation was an issue. Students who were extroverts tended to accumulate more discussion points than those who tended not to talk as much, even though the quiet students may have been academically excellent. This was noteworthy especially because class participation counted for $12.5 \%$ of the final grade.

There were rewards as well as challenges from teaching the course. First of all, students obtained an indepth knowledge of a subject that will help most of them on the job. One student commented that "learning information on SOX was very valuable." Second, some excellent papers were produced by students. One paper was published in a peer reviewed journal, while another was presented at a national conference and published in the conference proceedings. Finally, as faculty members who taught this course for the first time, we gained valuable experience. We will be able to incorporate "lesson learned" from our experience in this course into other courses or improve on this course in the future. 


\section{SUMMARY AND CONCLUSIONS}

Implementing a capstone course is a challenging and evolving process of making trial-and-error adjustments. It is also a time-consuming endeavor. We wrote this paper with four objectives in mind: 1) to share our experiences in designing and teaching a writing intensive accounting capstone course with a major topic focus, 2) to illustrate how the course accomplished the specified learning goals and to discuss issues and challenges that arose during the course, 3 ) to share our list of selected readings and grading rubric, and 4) to identify the challenges and rewards of creating a capstone writing course.

The overall quality of the research papers and information obtained from the grading rubrics and student teaching evaluations are evidence that most students felt that they benefited and/or will benefit from the experience. Anyone considering developing a capstone writing course at the undergraduate level should be aware that most accounting students have little or no experience in the process of writing a research paper from selection of a topic to a final draft of the paper. At the same time, we found that with proper preparation and guidance, most students embraced the opportunity to learn about a timely and controversial topic by reading and presenting research papers and to improve their writing skills by preparing a quality research paper.

\section{AUTHOR INFORMATION}

Sunita Ahlawat is Chair and Associate Professor of Accounting at The College of New Jersey. She is a 2008 Fulbright fellow, and holds a PhD from the Pennsylvania State University and an MBA from the University of Massachusetts. She has published in various journals including Advances in Accounting Behavioral Research, Auditing: A Journal of Practice \& Theory, Critical Perspectives on Accounting, International Journal of Technology Management, Journal of American Academy of Business, Journal of Behavioral Decision Making, Socio-Economic Review, and The Accounting Educators'Journal. E-mail: ahlawat@ @cnj.edu

Gerald J. Miller is an Associate Professor of Accounting at The College of New Jersey. He holds a PhD in Accounting from the University of Kentucky, is a Certified Public Accountant (Illinois) and a Certified Government Financial Manager. Dr. Miller has ten years of experience in Federal government auditing and five years of experience in private sector accounting. He has published in peer reviewed journals such as The Journal of Government Financial Management, The Accounting Educators' Journal and The Journal of Business and Public Affairs. E-mail: millerge@tcnj.edu. Corresponding author.

Abdus Shahid is a Professor of Accounting at The College of New Jersey. He holds a PhD in Accounting from Fox School of Business at Temple University and an MBA from Kelly School of Business, Indiana University. He has published papers in such journals as Accounting Enquiries, Advances in Managerial Accounting, American Business Review, Advances in Investment and Portfolio Management, Global Perspectives on Accounting Education, The Accounting Educators' Journal, Journal of Banking Regulation, and the Journal of Business and Economic Perspectives. E-mail: shahid@tcnj.edu

\section{REFERENCES}

1. AAC\&U (2007). College learning for the new global century. A report by Association of American Colleges and Universities.

2. AECC (Accounting Education Change Commission). (1990). Objectives of education for accountants: Position Statement No. 1. Issues in Accounting Education, 5(2), 307-312.

3. Arya, A., Fellingham, J. C. \& Schroeder, D. A. (2003). An academic curriculum proposal. Issues in Accounting Education 18(1): 29-35.

4. $\quad$ Bean, J. C. (1996). Engaging Ideas, Jossey-Bass Inc., San Francisco, CA.

5. Broadhead, G. J. (1999). Addressing multiple goals for engineering writing: The role of course specific websites. Language and Learning Across the Disciplines, 3(2), 19-43.

6. Burke, J., Katz, R., Handy, S. A., \& Polimeni R. S. (2008). Research skills: A fundamental asset for accountants, The CPA Journal, New York: January 2008. 
7. Carter, M., Ferzli, M., \& Wiebe E. N. (2007). Writing to learn by learning to write in the disciplines, Journal of Business and Technical Communication, 21(3), 278-302.

8. Coffin, C. (2003). Teaching Academic Writing: A Toolkit for Higher Education, Routledge, London.

9. Concordia College (2004). Goals of Liberal Learning, January 16; accessed at http://www.cord.edu/Academics/Dean/Committees/Corecommittee1/assets/Goals_Lib_Learn.pdf

10. Elkind, P., Gibney, A., and McLean, B. (2005). Enron: the smartest guys in the room.

11. Friedman, T. 2006. The world is flat: A brief history of the $21^{\text {st }}$ century. New York: Farrar, Straus, and Giroux.

12. Gardner, J. N., \& Van der Veer, G. (1998). The emerging movement to strengthen the senior experience. In The Senior Year Experience: Facilitating Integration, Reflection, Closure, and Transition, and experience, edited by J. Gardner, G, Van der Veer, and Associates, San Francisco, CA: Jossey Bass Publishers.

13. Henscheid, J. M. (2000). Professing the disciplines: An analysis of senior seminars and capstone courses. Monograph No. 30. Columbia, SC: University of South Carolina.

14. Jervis, K. J., \& Hartley, C. A. (2005). Learning to design and teach accounting capstone. Issues in Accounting Education, 20(4), 311-339.

15. Meacham, J \& J. G. Gaff. (2006). Learning Goals in Mission Statements: Implications for Educational Leadership, Liberal Education, Winter.

16. Romano, R. (2005). The Sarbanes-Oxley Act and the making of quack corporate governance. Yale Law Journal, 114, 1521-1561.

17. Sarbanes Oxley Act of 2002. http://www.sec.gov/about/laws/soa2002.pdf.

18. SEC (1998) Securities and exchange commission: A plain English handbook: How to create clear disclosure documents. http://www.sec.gov/pdf/handbook.pdf.

19. Siegel, G., \& Sorensen, J. E. (1994). What America wants in entry-level accountants. Management Accounting, 76, 26-31.

20. Simon, J., \& Alexander, D. (1997). Education, empiricism and the ethical dimension-a real life student centered research report. Accounting Education, 6(2), 163-175.

21. Schneider, C. G. 2005. President's message: Liberal Education and America's Promise. Liberal Education $91(1): 2-3$.

22. Solomon, D., \& Cassell, B. ( 2004). Companies complain about cost of corporate-governance Rules. The Wall Street Journal. (Eastern edition). New York, N.Y.: Feb 10, 2004. Pg. A.1.

23. Stowers, R. H., \& White, G. T., (1999). Connecting accounting and communication: A survey of public accounting firms. Business Communication Quarterly, 62(2), 23-40.

24. Thomas, C. W. (2002). The rise and fall of Enron, The Journal of Accountancy, April.

25. Titard, P. L., R. Braun, \& M. Meyer. (2004) Accounting Education: Response to Corporate Scandals, Journal of Accountancy, November.

26. VanZante, N.R. (2004). The new CPA examination. The CPA Journal, 64(4), 42-47.

27. Wright, A. (1994). Research in accounting: Student Perspectives. Journal of Accounting Education, 12(2), 161-174.

28. Zhang, I. X. (2007). Economics consequences of the Sarbanes-Oxley Act of 2002. Journal of Accounting and Economics, (44), 74-115.

29. Zekany, K. E., Braun, L. W., and Warder, Z. T. (2004). Behind closed doors at WorldCom: 2001, Issues in Accounting Education, February, Vol. 19.

30. Zinsser, W. K. (1988). Writing to Learn, Harper \& Row Publisher. 